\title{
ASSESSMENT OF RURAL HOUSEHOLDS FOOD INSECURITY DURING COVID-19 PANDEMIC IN SOUTH-EAST NIGERIA
}

\author{
Egwue Ogechi Lynda ${ }^{1}$, Agbugba Ikechi Kelechi ${ }^{*}$ iD $\square$, Mukaila Ridwan 3 (iD \\ $1,{ }^{* 2}$ Department of Agricultural and Applied Economics, Rivers State University, PMB 5080, Port \\ Harcourt, Nigeria \\ ${ }^{3}$ Department of Agricultural Economics, University of Nigeria Nsukka, Enugu State, Nigeria
}

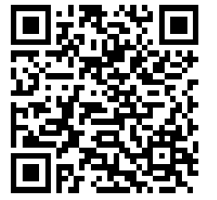

DOI: https://doi.org/10.29121/granthaalayah.v8.i12.2020.2713

Article Type: Research Article

Article Citation: Egwue Ogechi Lynda, Agbugba Ikechi Kelechi, and

Mukaila Ridwan. (2020).

ASSESSMENT OF RURAL HOUSEHOLDS FOOD INSECURITY DURING COVID-19 PANDEMIC IN SOUTH-EAST NIGERIA.

International Journal of Research GRANTHAALAYAH, 8(12), 182-194. https://doi.org/10.29121/granthaa layah.v8.i12.2020.2713

Received Date: 11 November 2020

Accepted Date: 31 December 2020

\section{Keywords:}

Households

Food Security Index

Logistic Regression

COVID-19 Pandemic

Nigeria

\section{ABSTRACT}

The problem of food insecurity remains a challenge in developing countries, especially in rural areas. Despite the rising level of food insecurity, COVID-19 set in and was said to pose a threat to food security globally if adequate measures are not quickly put in place. This study, therefore, described the socio-economic characteristics of the respondents; examined the extent to which the rural households are food secure or otherwise during the COVID-19 pandemic and examine the drivers of food security status among rural households in South-East Nigeria. Primary data were collected from 200 households with the use of structured questionnaires. Data were analysed using descriptive statistics, food security index and logistics regression. Results of the findings revealed that the majority of the household heads were male (92\%), married (93.5\%), educated (87.5\%) and had an average age of 54 years. They had an average household size of 7 persons, an average farming experience of 22 years, an average monthly income of $\$ 14,305.5$ and majority $(83 \%)$ do not belong to a cooperative society. Majority $(69.5 \%)$ of the households were food insecure, while only (30.5\%) were food secure. The food-secure households had an average household size of 5 persons, while the food insecure households had 9 persons in their households. The headcount ratio of food secure households was 0.30 , while it was 0.70 for food-insecure households. This shows that at least two out of three persons were food insecure in the study area. The surplus/shortfall index indicates that the food secure households exceeded the calorie requirement by $12 \%$, while the food insecure fell short of the recommended calorie intake by $39 \%$. Square food insecure gap or square shortfall index which indicate the severity of food insecurity among the food insecure household was 0.0056. The average calorie available (adult equivalent per day) for food secure households was $2523.5 \mathrm{kcal}$, while average calorie available (AE/day) for food-insecure households was $1389.05 \mathrm{kcal}$. The identified positive drivers of food security were marital status, educational level, cooperative members and annual income of the household heads. While, age of household head, household size and COVID-19 negatively influenced food security status.

The study recommends, among others, putting in place immediate policy measures to reduce the effect of COVID-19 pandemic on rural household's food security through the provision of enough palliatives which should be monitored so that it gets to the targeted population. Effective household size management and enlightenment programs on modern family planning techniques should be encouraged in rural areas. Rural households should also be educated on the nutritional implication of the various food items such as egg, milk, soybean and fish, especially for children to increase their protein intake and boost their immune system against COVID-19.

\section{INTRODUCTION}

Food insecurity is a situation where a person is unable to get a sufficient amount of healthy food on a daily basis. The United State Department of Agriculture (USDA) in 2018 describes food insecurity as a situation in which regular access to adequate food is limited by lack of money and other necessary resources. Food insecurity remains a global

(c) 2020 The Author(s). This is an open access article distributed under the terms of the Creative Commons Attribution License, which permits unrestricted use, distribution, and reproduction in any medium, provided the original author and source are credited. 
challenge and reducing it continues to be a major public policy in developing nations. Over 820 million people are undernourished globally (FAO, 2019). Many more suffer from micronutrient deficiencies, and the absolute numbers tend to increase further, especially in Sub-Saharan Africa (FAO, 2008). Despite many efforts to improve and increase food production and quality globally, many citizens of Africa and Asia have died due to malnutrition (Matemilola \& Elegbede, 2017).

Food security is national security and household head are faced with the responsibility of feeding his/her household. A nation also has to improve the food security status of her populace. Reliable information on household food security is a pre-requisite for effective and accurate design, monitoring and development of development projects (Charletto, 2001). Hence many development agencies considered household food security a guiding principle for designing interventions in rural areas. Measuring food security at the farm family level will provide the basis for monitoring future progress and assessing the impacts of various projects, programmes and policies on the beneficiaries' food security status (Hoddinot \& Johannes, 2001). Besides, the community-based assessment measure will ensure that underlying social, economic, and institutional factors within a community that affect the quantity and quality of available food and its affordability are evaluated and made fit for intervention projects.

Recent COVID-19 pandemic has contributed to greater public awareness of hunger-related problems, also resulting in new international commitments to invest in developing countries agriculture. Nigeria is part of the phenomenon of food insecurity, Global Hunger Index (GHI) ranked Nigeria 40th among 79 food deficient nations in 2011, ranked 40th again in 2012, 39th in 2013 and 38th in 2014 remains unacceptably high (GHI, 2011, 2012, 2013 \& 2014). The GHI Report (2012) further posits that rising food prices, malnutrition and deaths as a result of widespread poverty is an indication of the prevalence of food insecurity in the country.

The rural areas which engaged in agricultural production are the most hit in terms of food insecurity and poverty as food security was reported to be more endemic in rural areas (Nigeria Millennium Development Goals (MDGs) End-point report, 2015). From the above, it is obvious, that the continuous efforts of the government did not arrest the food insecurity situation and hence resort to complement its internal effort with the importation of food.

Food insecurity is a global phenomenon, about 795 million people are undernourished globally (FAO, 2015). Food insecurity is one of the major problems of developing countries as about 779.9 million people are food insecure in developing regions (FAO, 2015). It is well known that most countries in Africa are still food insecure and Nigeria is part of this phenomenon. Achieving food security in Africa remains a challenge as about 232.5 million people in Africa are undernourished (FAO, 2015) the state of food insecurity keeps increasing in Africa as about 181.7 million people are food insecure in 1990, 210 million people are food insecure in 2000, 213 million people are food insecure in 2005, 218.5 million in 2010 and 232.5 million in 2014-16. In West Africa, about 33.7 million are food insecure (FAO, 2015).

According to current statistics, in Nigeria alone, about 25.6 million people were undernourished between 20162018 while 12.1 million people faced severe food insecurity problem between 2015 -2017 (FA0, 2020). In Nigeria, especially the rural areas, the problem of food insecurity is still a major challenge. Over $40 \%$ of households across all agro-ecological zones in Nigeria face the problem of severe food insecurity (Idachaba, 2004). The problem of food insecurity has been in existence for long as back as early 1960s after the discovery of oil in Nigeria and many government programs have been developed yet the food insecurity problem seems increasing alongside with increase in population. Also, Nigeria is unable to meet the 1996 world food summit (WFS) target of having the number of hungry people to reduce by half by 2015 , this shows food insecurity is still a major problem in Nigeria. Malnutrition is widespread in the entire country and rural areas and communities are especially vulnerable to poor quality foods, erratic food supply, unbalanced nutrition, chronic food shortages, malnutrition, high food costs and even total lack of food.

With the current COVID-19 pandemic which poses a threat to the food system by reducing the food supply and increasing the price tagged to it. Nigeria populace are endangered with the problem of food insecurity. Millions of people were affected due to the interruption caused by COVID-19 pandemic on the food supply chains which creates food shortage (Agbugba, 2020). The resources of a region become less available when COVID-19 pandemic ramp up in such region, thereby interrupting the food supply chain reliant on deliveries from a region experiencing high rate of the infection (Agbugba, 2020).

Several studies have been done to examine food security determinants in the country. This study includes Obasan et al. (2017); Ambali et al. (2015); Oyebanjo et al.(2013); Omotesho, Adewumi and Ayinde (2006); Babatunde et al. (2007); Babatunde \& Qaim (2010); Agboola, (2004). But there is no study that assessed the present food security situation of the country due to COVID-19 pandemic most especially in the rural areas. The current 
Assessment of Rural Households Food Insecurity During Covid-19 Pandemic in South-East Nigeria

COVID-19 pandemic requires research that will reassess the food security of rural people to investigate if the COVID19 has affected the food security status of people and how people are coping with the food insecurity due to COVID19 pandemic.

\subsection{OBJECTIVES OF THE STUDY}

The broad objective of this study was to investigate the food security status of rural households during the COVID-19 pandemic. To pursue this main objective some specific objectives were also aimed at in this study.

These specific objectives were to:

1) Describe the socioeconomic characteristics of rural households

2) Examine the extent to which the rural households are food secure or otherwise during the COVID-19 pandemic;

3) Examine the drivers of food security status among rural households.

\section{METHODOLOGY}

This study was conducted in Enugu State, South-East Geopolitical Zone of Nigeria. The area is one of the 36 States of Nigeria and lies between latitudes $5^{\circ} 56^{\circ} \mathrm{N}$ and $7{ }^{\circ} 05^{\circ} \mathrm{N}$ of the Equator and longitudes $6^{\circ} 53^{\circ} \mathrm{E}$ and $7^{\circ} 55^{\circ} \mathrm{E}$ of the Greenwich meridian (Enugu State Agricultural Development Programme [ENADEP], 2014). It shares boundaries in the West with Anambra State; in the south with Abia State; in the North with Benue and Kogi States; and in the East with Ebonyi State. The region occupies a landmass of approximately 8,022.95 $\mathrm{km}^{2}$ with a population of about 3,257,298 (ENADEP, 2016).

The State consists of 17 Local government areas (LGAs) and it is divided into six agricultural zones (ENADEP, 2015). The rural areas of the state engaged in agricultural activities where agricultural accounted for a significant percentage of their workforce.

\subsection{SAMPLING TECHNIQUES}

A three-stage random sampling technique was used in the selection of the respondents as follows:

In the first stage, five local governments were randomly selected out of the seventeen LGAs in the state. Second state-stage involved the random selection of two rural communities from each local government, making a total of ten rural communities. The last stage was a random selection of twenty households from each rural community making a total of 200 rural households for this study.

\subsection{DATA COLLECTION METHOD AND SOURCES}

In other to satisfy the idea of this research work, primary data were adopted which were collected from rural households of Enugu State. The primary data was from a target population (200 households) consisting of rural farming household units. The primary data covered information such as socio-economic characteristics, food consumed by households (calorie intake of households), and the types of food consumed by households during the food insecurity period of COVID-19 pandemic.

\subsection{METHOD OF DATA ANALYSIS}

Descriptive statistics, food security indices, logistic regression, household dietary diversity and Likert rating scale were the analytical tools used for this study. Objective (i) was achieved using descriptive statistics such as mean, frequency and percentages. Objective (ii) was achieved using food security indices, objective (iii) was achieved using logistic regression 


\subsection{DESCRIPTIVE ANALYSIS}

The descriptive statistical analyses used included frequency distribution tables, the measure of central tendency and a measure of a dispersion including measures of mean and percentage. These were used to describe the socioeconomic characteristics of the respondent and to present the results of the findings.

\subsection{FOOD SECURITY INDICES}

To measure household food security, a food security index was constructed. This involved using a daily minimum recommendation level of $2260 \mathrm{kcal}$ per capita per day by Food and Agriculture Organisation were adopted as the food security line for the study. This follows the study of Omotesho, et al. (2006). Any household that has below $2260 \mathrm{kcal}$ was considered food insecure and equal or above considered as food secure household. The daily per capita calorie consumption was estimated by dividing the estimated daily calorie supply to the household by the household size (adult equivalent) using the equivalent male adult scale weights while calorie availability was estimated using food nutrient composition.

Food security index $\mathrm{Z}=\frac{\text { Household's daily per capita calorie availability (A) }}{\text { Household's daily per capita calorie requirement (I) }}$

For this study, a household is defined as a group of people living together and eating from the same pot.

The Headcount ratio $(\mathrm{H})$ is a measure of food security status and it is defined as

Where,

$$
H=\frac{M}{N}
$$

$M=$ the number of the food-insecure

$\mathrm{N}=$ sample population

Food insecurity Gap: this a measure of the depth of food insecurity and it is expressed as:

Where,

$$
F I G_{i}=\frac{T C R_{i}-T C C_{i}}{T C R_{i}}
$$

$\mathrm{FIG}_{\mathrm{i}}=$ Food insecurity Gap of $\mathrm{i}^{\text {th }}$ Food insecurity household

$\mathrm{TCC}_{\mathrm{i}}=$ Total calorie consumption by ith Food insecurity household

$\mathrm{TCR}_{\mathrm{i}}=$ total calorie requirement for ith Food insecurity household

The total food insecurity gap or shortfall index is expressed as:

$$
T F I G=\frac{\sum\left(T C R_{i}-T C C_{i}\right)}{T C R_{i}}
$$

Square food insecure Gap: this indicate the severity of food insecurity among the food insecure household and it is given as:

$$
S F I G=\frac{\sum\left(F I G_{i}\right)^{2}}{M}
$$

\subsection{LOGIT REGRESSION MODEL}

In analysing the determinant of food security among the rural household logistic regression was used. This model was used for estimating the probability that an event occurs having a dichotomous dependent variable: 1 for a food secure and 0 for food-insecure household. The logistic regression model was used, is expressed as: 
The logistic regression model in implicit form is

$F S I_{i}=\mathrm{f}$ (AGE, GEN, MAR, HHS, EDU, FS, COP, INC, COV, $\varepsilon$ )

The logistic regression model is specified explicitly in the linear form as:

$$
F S I_{i}=\beta_{0}+\beta_{1} A G E+\beta_{2} G E N+\beta_{3} M A R+\beta_{4} H H S+\beta_{5} E D U+\beta_{6} F S+\beta_{7} C O P+\beta_{8} I N C+\beta_{9} C O V+\varepsilon_{i}
$$

Where

FSI $_{\mathrm{i}}$ (dependent variable) $=$ food security indicator of farming households $(1$ for food secure; 0 for food insecure).

The independent variables $\left(\mathrm{X}_{\mathrm{i}}\right)$ included in the model include:

AGE $=$ Age of the household head

GEN $=$ Gender of the household head

MAR = Marital status of the household head

HHS $=$ Household size in adult equivalent

EDU $=$ Educational status of the household head

FS $=$ Farm size of the household head

$\mathrm{COP}=$ Cooperative membership ( $1=$ yes, $0=$ no)

INC = Income of the household head (Naira)

COV = COVID-19 (measured in term of effect of lockdown on household food availability: $1=$ yes, $0=$ no)

$\varepsilon_{i}=$ Random error term

\section{RESULTS AND DISCUSSION}

This chapter provides the empirical analysis of the socioeconomic characteristics of the rural households, food security status of the rural households including their drivers, dietary diversity of the households during the COVID19 pandemic. This mainly comprises descriptive statistics, food security index and logistic regression model.

\subsection{DESCRIPTION OF RURAL HOUSEHOLDS BASED ON THEIR SOCIO-ECONOMIC CHARACTERISTICS}

Table 1.0 presents the socio-economic profiles of the rural household heads. The table revealed that the majority $(92 \%)$ of the household heads were male. This suggests that the males were the decision taker among rural households. While the female household heads account for only $8 \%$ of the population. It was observed during the survey that the female-headed households were those that their husband stays in another city and those that were widowed.

Regarding the rural household heads age, the larger proportion (35\%) of them were within the age range of 51 to 60 years, the least (14.5\%) fall within the age group of 30 to 40 years. Their average age was 54 years. This suggests that the rural household heads were adults who are quite advanced in age, though still economically active and viable to engage in agricultural activities. The age of a farmer plays a significant role in their productivity as the majority of farmers in Nigeria operate on a small scale with the use of crude implements which requires energy and strength for its operation.

The majority (93.5\%) of the respondents were married, while $4 \%$ and 2.5 were single and widowed respectively. This suggests that this study targeted the right population for this research as research related to food security require households. The higher percentage of the married respondents suggests that the respondents had household members living with them either as their children or extended families.

Concerning their educational status, almost half (49\%) of the household heads had only primary school education, $34 \%$ had secondary school education and $4.5 \%$ had tertiary school education. While only $12.5 \%$ did not have any formal education. This result suggests that level of literacy was relatively high among the rural household heads in the study area. The higher level of education is expected to assist farmers in adopting innovation on best agricultural practice.

The rural households had an average household size of 7 persons per household with a majority (58.5) having between 6 and 9 persons. This suggests that rural households had a relatively large household size. This is not 
surprising as rural people love to have a larger household size which can be engaged in agricultural activities as their cheap family labour. Most of the rural households also leave with their extended family.

Regarding their farm size, the majority (55\%) had between 1.41 to 2.39 hectares while the minority (6.5) had above 4 hectares of farmland. Their average farm size was 2.1 hectares, this implies that the rural households were operating on small-scale farming.

Cooperative membership was very low in the study area as only $17 \%$ participated in a cooperative society. Cooperative association help farmers to pool their resources together to enjoy the economies of scale and also assist them financially.

Regarding the household heads monthly income, the larger proportion (46\%) of the rural household heads had between $\$ 10,001$ to $\$ 20,000$ while a few of them had more than $\$ 30,000$ monthly income. On average the rural household heads had $\$ 14,305.5$ monthly income. The rural household heads disclosed during the interview that their lower-income was as a result of the present pandemic which affected their movement and productivities.

The larger proportion (27.5\%) of the household heads had between 11 to 20 years of farming experience, 22\% had between 21 to 30 years, $19.5 \%$ had $31-40$ years of framing experience. The time length spent in an enterprise determines the skill acquired in such professional, therefore, the rural household heads in the study area can be described as well experienced farmers who were knowledgeable about farming activities.

As regards, their major source of fund, the majority (93\%) of the household heads used their fund for farming activities, while only $6.5 \%$ and $0.5 \%$ source their major fund from cooperative society and bank respectively. This suggests low credit accessibility in the study area. Using personal fund hinders and determine farmers' level of operation. This could be the reason why the farmers were operating on a small-scale level as the personal fund is not enough to operate on large-scale farming.

Table 1: Socio-economic Characteristics of the Rural Households

\begin{tabular}{|c|c|c|c|c|}
\hline Characteristics & Categories & Frequency & Percentage & Mean \\
\hline \multirow[t]{2}{*}{ Gender of household head } & Male & 184 & 92 & \\
\hline & Female & 16 & 8 & \\
\hline \multirow[t]{4}{*}{ Age of household head } & $30-40$ & 29 & 14.5 & 54 \\
\hline & $41-50$ & 65 & 32.5 & \\
\hline & $51-60$ & 70 & 35 & \\
\hline & $>60$ & 36 & 18 & \\
\hline \multirow[t]{3}{*}{ Marital status } & Married & 187 & 93.5 & \\
\hline & Single & 8 & 4 & \\
\hline & Widow & 5 & 2.5 & \\
\hline \multirow[t]{4}{*}{ Education } & No formal education & 25 & 12.5 & \\
\hline & Primary education & 98 & 49 & \\
\hline & Secondary education & 68 & 34 & \\
\hline & Tertiary education & 9 & 4.5 & \\
\hline \multirow[t]{2}{*}{ Household size } & $\begin{array}{l}2-5 \\
6-9\end{array}$ & $\begin{array}{c}68 \\
117\end{array}$ & $\begin{array}{c}34 \\
58.5\end{array}$ & 7 \\
\hline & $>9$ & 15 & 7.5 & \\
\hline \multirow[t]{4}{*}{ Farm size (ha) } & $0.39-1.39$ & 46 & 23 & 2.1 \\
\hline & $1.41-2.39$ & 110 & 55 & \\
\hline & $2.4-3.99$ & 31 & 15.5 & \\
\hline & $>4$ & 13 & 6.5 & \\
\hline \multirow[t]{2}{*}{ Cooperative membership } & Non-member & 166 & 83 & \\
\hline & Member & 34 & 17 & \\
\hline \multirow[t]{4}{*}{ Monthly income ( } & $<10,000$ & 70 & 35 & $14,305.5$ \\
\hline & $10,001 .-20,000$ & 92 & 46 & \\
\hline & $20,001-30,000$ & 31 & 15.5 & \\
\hline & $>30,000$ & 7 & 3.5 & \\
\hline Farming experience (years) & $<10$ & 48 & 24 & 22 \\
\hline
\end{tabular}


Assessment of Rural Households Food Insecurity During Covid-19 Pandemic in South-East Nigeria

\begin{tabular}{|c|c|c|c|c|}
\hline & $11-20$ & 55 & 27.5 & \\
\hline & $21-30$ & 44 & 22 & \\
\hline & $31-40$ & 38 & 19.5 & \\
\hline & $>40$ & 14 & 7 & \\
\hline Major source of fund & Personal & 186 & 93 & \\
\hline & Cooperative & 13 & 6.5 & \\
\hline & Borrow from bank & 1 & 0.5 & \\
\hline & Total & 200 & 100 & \\
\hline
\end{tabular}

Source: Field survey, 2020

\subsection{DESCRIPTIVE STATISTIC RESULTS OF HOUSEHOLD FOOD SECURITY STATUS}

As shown in Table 2.0, the majority of rural households were food insecurity. This was indicated by a larger percentage of $69.5 \%$ of food-insecure households while only $30.5 \%$ were food secure. The current level of food insecurity was higher than what has been reported in rural areas of Nigeria before the COVID-19 pandemic. For instance, Onunka et al. (2018) in their study reported only $42 \%$ of food insecurity in Enugu State; Irohibe \& Agwu (2014) reported that only $26 \%$ of the rural household were food insecure in their study; and Oyebanjo et al. (2013) reported $40.8 \%$ of food insecurity. This suggests that the COVID-19 had increased the food insecurity level of the rural households of the study area.

Table 2: Distribution of respondents according to the food security status

\begin{tabular}{|c|c|c|}
\hline Food security status & Frequency & Percentage \\
\hline Food secure & 61 & 30.5 \\
\hline Food insecure & 139 & 69.5 \\
\hline Total & 200 & 100 \\
\hline
\end{tabular}

Source: Field Survey, 2020

\subsection{SUMMARY OF FOOD SECURITY INDEX}

Table 3.0 presents a summary of the food security indices. As shown in the table, the food secure household had an average household size of 5 persons while the food insecure households had an average household size of 9 persons in their households. This implies that households with smaller size were food secure while those with larger household hold size were food insecure. The headcount ratio of food secure households was 0.30 while it was 0.70 for food-insecure households. This implies that for every 10 persons in the study area, only three persons were food secure while 7 persons were food insecure. It can further be stated that for every 3 persons selected in the area, two persons were food insecure while only one person was food secure. The headcount ratio further suggests that only $30 \%$ of the individuals in the study area were food secure while $70 \%$ of these individuals were food insecure subsisting on less than the minimum recommended calorie intake of $2260 \mathrm{kcal}$.

The surplus/shortfall index which is a measure of the depth of food insecurity or measures the extent of deviation from the food security line indicates that the food secure households exceeded the calorie requirement by $12 \%$, while the food insecure fell short of the recommended calorie intake by $39 \%$. This suggests that the food insecure households were relatively far from the food security line. Square food insecure gap or square shortfall index which indicate the severity of food insecurity among the food insecure household was 0.0056 .

The average calorie available (adult equivalent per day) for food secure households was $2523.5 \mathrm{kcal}$ while average calorie available (adult equivalent per day) for food-insecure households was $1389.05 \mathrm{kcal}$. The total average calorie intake among the rural areas was $1602.63 \mathrm{kcal}$ adult equivalent per day. These results imply that food security is still a major challenge in the rural area and the current pandemic has added to the problem.

Table 3: Summary of Food Security Indices

\begin{tabular}{|c|c|c|c|}
\hline Food Security Indices & Food Secure & Food Insecure & All \\
\hline Percentage household & 30.5 & 69.5 & 100 \\
\hline
\end{tabular}


Egwue Ogechi Lynda, Agbugba Ikechi Kelechi, and Mukaila Ridwan

\begin{tabular}{|c|c|c|c|}
\hline Average household size (AE) & 5 & 9 & 7 \\
\hline Surplus/shortfall index (P) & 0.12 & 0.39 & \\
\hline Square food insecure Gap & & 0.0056 & \\
\hline Head count ratio & 0.3 & 0.7 & \\
\hline Calorie available (AE/day) & 2535.5 & 1381.35 & 1602.63 \\
\hline
\end{tabular}

Source: Field survey, 2020

\subsection{RESULT OF LOGISTIC REGRESSION TO IDENTIFY THE DRIVERS OF RURAL HOUSEHOLDS FOOD}

\section{Security Status}

Table 4.0 presents the result of the logistic regression used to identify the drivers of food security status among rural households. Seven variables were found to be the significant factors influencing the food security status of rural households. They were the age of household head, marital status, household size, educational level, cooperative members, the annual income of the household heads and COVID-19. The model has a good fit as indicated by LR chisquare of 40.44 which was however significant at $1 \%$. The Pseudo R-square of 0.16 seems low but not uncommon to field survey data.

The coefficient of the age of household head was negatively and statistically significant at $10 \%$. This suggests that as the age of the household heads increases, the probability of being food secure decreases. As the major occupation of most rural household heads was farming which requires strength and energy for its operation, an ageing farmer will not have the required energy to use the crude implements. This thus lowers their output, income and reduce their probability of being food secure. This disagreed with the finding of Ibok et al. (2014) who reported that the age of the household heads had a positive effect on the food security status of urban households. This could be as a result of the fact that urban households did not engage in agricultural activities which require energy.

The coefficient of household head marital status was positively related to food secure status (at $5 \%$ significant level). This suggests that married household heads had the tendency of being food secure than their counterpart. This is as a result of the fact that married households will combine their resources (money) to feed their households and have a good plan on how to manage their resources.

The coefficient of the household size was negatively significant at $1 \%$ in relation to the food security status of the rural households. This conforms to a priori expectation as larger household size put great pressure on the household heads in term of providing food for their households. This result implies that a household with smaller size were more food secure than their counterpart, while the larger household size was food insecure. This conforms with the findings of Obasan et al. (2017); Ibok et al (2014) Frimpong and Asuming-Brempong (2013); Omotesho et al. (2006); Oyebanjo et al. (2013) that the households with few members are more food secure and those with larger size were food insecure.

The educational level of the household head was significant at $5 \%$ and positively related to household food security status. This suggests that households with a well-educated household head are likely to be more food secure than those with uneducated household heads. This could be as a result of engaging in family planning by the educated household heads. Level of education also determines the level of innovation being adopted by a farmer and their level of exposure to information such as family planning. This is in line with the findings of Ibok et al (2014); Oyebanjo et al. (2013) who reported that education had a positive effect on food security.

The coefficient of cooperative membership was also positively related to food security at $5 \%$ level of significance. This suggests that being a member of a cooperative will increase the probability of being food secure. It further implies that a household which its household head belongs to a cooperative society are more food secure than those that their heads did not belong to a cooperative society. This could be as a result of enjoying economies of scale by cooperative members in terms of buying and selling items at lower prices. It could also be due to the financial and material support that such households could receive from cooperatives which those who are not members may not. Oyebanjo et al. (2013); Henri-Ukoha et al. (2013) reported the same thing that cooperative membership influence food security positively.

The annual income of the household heads was significant and positively related to household food security at $10 \%$. This suggests that as the household heads income increases, the probability of being food secure also increase. This conforms with a priori expectation as being food secure require money to purchase foods that are not produced in their farm. The implication of this result is that household heads with higher annual income were more food 
insecure than those with lower income. Higher-income household heads may probably have much money to procure food items for consumption while a household with lower income may have less to spend on consumption. This conforms with the findings of Obasan et al. (2017); Muche and Tadele (2015); Ibok et al (2014); Omotesho et al. (2006) that income influenced the food security status of people positively.

COVID-19 was significant and negatively related to food security at $10 \%$. This implies that COVID-19 had a negative effect on food security status of rural households and had increased the level of food insecurity in the rural areas of Nigeria. It further suggests that as the current pandemic continues, the probability of being food insecure will increase in rural households if immediate and effective measures are not taking.

Table 4: Factors influencing Food Security Status of Rural Households

\begin{tabular}{|c|c|c|c|c|}
\hline Variables & Coeff. & Std. Error & T-value & P-value \\
\hline Age of household head & -0.0309299 & 0.0170214 & -1.82 & 0.069 \\
\hline Gender of household head & 0.9822872 & 0.7174494 & 1.37 & 0.171 \\
\hline Marital status & 0.7098379 & 0.3268886 & 2.17 & 0.030 \\
\hline Household size (Adult equivalent) & -0.4812442 & 0.1552029 & -3.10 & 0.002 \\
\hline Educational status & 0.1323166 & 0.0602634 & 2.20 & 0.028 \\
\hline Farm size (hectare) & -0.139437 & 0.2283215 & -0.61 & 0.541 \\
\hline Cooperative members & 1.157179 & 0.4534488 & 2.55 & 0.011 \\
\hline Annual income & $5.70 \mathrm{e}-06$ & $2.95 \mathrm{e}-06$ & 1.93 & 0.054 \\
\hline COVID-19 & -.554063 & 0.3333244 & -1.66 & 0.096 \\
\hline cons & -2.747217 & 1.602808 & -1.71 & 0.087 \\
\hline LR chi2 $(9)=40.44$ & & & & \\
Prob > chi2 $=0.0000$ & & & & \\
Pseudo R $=0.1569$ & & & & \\
Log likelihood $=-108.63918$ & & & & \\
\hline
\end{tabular}

Source: Field survey, 2020

\section{CONCLUSION}

This study assessed the food security status of rural households during COVID-19 pandemic in Enugu State, Nigeria. The study employed primary data collected from 200 households with the use of structured questionnaires. The data were analysed using descriptive statistics, food security index, logistics regression, household dietary diversity score and Likert rating scale. Hence, the study concluded that the current level of food insecurity was higher than what has been reported in rural areas of Nigeria before the COVID-19 pandemic. It can be inferred from the findings of this study that COVID-19 had a significant negative impact on the food security status of rural households in Nigeria. This study also showed that households with smaller size were food secure while those with larger household hold size were food insecure and that majority of the rural households concentrated their diet on less than four types of food out of twelve food used to measure their dietary diversity, this indicates a poor-quality food intake.

\section{RECOMMENDATIONS}

Based on the findings of the study, the following recommendations are proffered:

Government should put in place immediate policy measures to reduce the effect of COVID-19 pandemic on rural household's food security. This could be achievable through the provision of enough palliative which should be monitored to be sure it gets to the targeted population.

Effective household size management and enlightenment programs on modern family planning techniques should be encouraged in the study area so that they may bear children that their resources can accommodate.

Food security is partly a production issue; thus, the government should focus on sustainable agricultural productivity which will lead to increased agricultural production, development of agricultural market channels and enough food. Particular attention should be paid to smallholder farmers in efforts to increase agricultural productivity and production since the smallholder farmers produce the food consumed in Nigeria. 
Policy measures that will boost rural household head income should be put in place by governments and other relevant bodies. This could be achieved through providing credit facilities which will be available, accessible and affordable by the farmers. This will boost their agricultural productivities and move some farmers from small-scale farming to large scale farming.

Education should be encouraged in rural areas and incentives created to encourage rural dwellers to pursue education. Rural households need to be educated on the nutritional implication of the various food items such as egg, milk, soybean and fish especially for growing children to increase protein intake in their diet and boost their immune system against COVID-19. This is necessary for the food insecure households to be able to make appropriate choices in matters of food consumption.

\section{SOURCES OF FUNDING}

This research received no specific grant from any funding agency in the public, commercial, or not-for-profit sectors.

\section{CONFLICT OF INTEREST}

The author have declared that no competing interests exist.

\section{ACKNOWLEDGMENT}

None.

\section{REFERENCES}

[1] Abimbola 0. A. and Kayode A. A. (2013). Food insecurity status of rural households during the post-planting season in Nigeria. Journal of Agriculture and Sustainability 4(1): 16-35.

[2] Adejuwon, J.O. (2006). Food Crop Production in Nigeria: Potential Effects of Climate Change. Climate Research 32: 229-245.

[3] Agada, M. O., \& Igbokwe, E. M. (2015). Food Security and Coping Strategies among Ethnic Groups in North Central Nigeria. Developing Country Studies 4(8), 31-45.

[4] Agboola, P.O. (2004). Analysis of Food Insecurity and Coping Strategies among Farming Household in Osun State. Unpublished PhD Thesis. University of Ibadan, Nigeria

[5] Agbugba, I. K. (2020). IFAMA Goes Digital: COVID-19 Pandemic has Reaffirmed the Need to Develop Nigeria's Agriculture Sector, Food for the Future, International Food \& Agribusiness Management Association, Rotterdam, The Netherlands. Available online: https://www.foodlog.nl/ ifama/article/dr.-ikechi-agbugbacorona-has-reaffirmed-the-need-to-develop-nigerias-agric (Wednesday, June 10th)

[6] Agbugba, I. K. (2020). How Federal Government can make Agriculture sustainable in Post-COVID-19 Pandemic Season, Exclusive Interview: AGRONIGERIA. Available online: https: agronigeria.ng/2020/05/18/exclusive-interview-how-fg-can-make-agriculture-sustainable-post-covid-19agbugba/ (Monday, May 18th)

[7] Ahmed F. F., Eugene, C. E. and Abah, P. O. (2015). Analysis of Food Security among Farming Households in Borno State, Nigeria. Journal of Agricultural Economics, Environment and Social Sciences 1(1): 130-141

[8] Akinyele, I.O. (2009). Ensuring Food and Nutrition Security in Rural Nigeria: An Assessment of the Challenges, Information Needs, and Analytical Capacity. NSSP Working Paper 7. Abuja, Nigeria: International Food Policy Research Institute (IFPRI). http://ebrary.ifpri.org/cdm/ref/collection/p15738coll2/id/22824

[9] Ambali, O. I., Adewuyi, S. A., Babayanju, S. O., \& Ibrahim S. B. (2015). Expansion of Rice for Job Initiative Programme: Implications for Household Food Security in Lagos State Nigeria. Advances in Economics and Business 3(3): 99-106, 2015 http://www.hrpub.org DOI: https://doi.org/10.13189/aeb.2015.030303

[10] Babatunde, R. O., Omotesho, O. A., \& Sholotan, O. S. (2007). Socio-Economics Characteristics and Food Security Status of Farming Households in Kwara State, North-Central Nigeria. Pakistan Journal of Nutrition, 6(1), 4958. 
Assessment of Rural Households Food Insecurity During Covid-19 Pandemic in South-East Nigeria

[11] Babatunde, R. O., \& Qaim, M. (2010). Impact of Off-farm Income on Food Security and Nutrition in Nigeria By Impact of Off-farm Income on Food Security and Nutrition in Nigeria. Conference of Africa Association of Agricultural Economists, "Africa and the Global Food and Financial Crises", 19 - 23 September 2010, Cape Town, South.

[12] Bergeron, G., Morris, S. and Banegas, J. (1998). How Reliable are Group Informant Rating-A Test of Food Security Rating in Honduras. World Development. 26(10), 1893-1902.

[13] Central Bank of Nigeria, 2017. Real Gross Domestic Product (Million Naira) http//www.cbn.gov.ng/rates/RealGDP.asp?year=2017.

[14] De Sousa, A. (2020). Tracking COVID-19. Bloomberg News. Retrieved from https://www.bloomberg.com/graphics/2020-coronavirus-dash/

[15] Devereux, S., 2002, 'Poverty, Livelihoods \& Famine', paper prepared for the Ending Famine in the 21st Century Conference, 27 February-1 March 2002, Institute of Development Studies, University of Sussex, UK.

[16] Devereux S., Baulch B., Hussein K., Shoham J., Sida H. and Wilcock D. (2004). Improving the analysis of food insecurity, food security measurement, livelihood approaches and policy: Application in FIVIMS. FIVIMS mimeographed.

[17] Devereux, S. (2002). Community Adaptation and Sustainable Livelihood: Basic Issues and Principles. (www.fao.org/document/showscdr.asp)

[18] Devereux, S. (2001). Livelihood Insecurity and Social Protection: Re-Emerging Issue in Rural Development. Development Policy Review, 19(4),517-519.

[19] Ellis, F. (2000). Rural Livelihoods and Diversity in Developing Countries, Oxford, OUP.

[20] Eluhaiwe, P.N. (2008). The Central Bank of Nigeria Partnership with Alliance for a Green Revolution in Africa (AGRA): Conceptual Issues, Operations and Prospects for Food Security in Nigeria. In Central Bank of Nigeria Economic and Financial Review, 48(4).

[21] ENADEP 2016. Enugu State Agricultural Development Programme; Annual Report, pp 27. Published by Enugu State Government of Nigeria.

[22] ENADEP 2014. Enugu State Agricultural Development Programme; Annual Report, pp 27. Published by Enugu State Government of Nigeria.

[23] Food and Agricultural Organisation, 2019. The State of Food Insecurity in the World. Food and agricultural organization of the United Nations. (FAO) Rome.

[24] Food and Agricultural Organisation (2015). The state of food insecurity in the World. Food and agricultural organization of the United Nations.

[25] Food and Agriculture Organization (2008). The State of Food Insecurity in the World 2008.Food and Agriculture Organization, Rome.

[26] Food and Agriculture Organization (2007). The State of Food Insecurity in the World 2008.Food and Agriculture Organization, Rome

[27] Food and Agriculture Organization (2002). The State of Food Insecurity in the World 2001. Food and Agriculture Organization, Rome.

[28] Food and Agriculture Organization (1983). World Food Security: A Reappraisal of the Concepts and Approaches. Director General's Report. Rome.

[29] Food and Agriculture Organization (1996). Rome Declaration on World Food Security and World Food Summit Plan of Action. World Food Summit 13-17 November 1996. Rome.

[30] Food and Agriculture Organization (1996a). Socio-Political and Economic Environment for Food Security, Food and Agriculture Organization of The United Nations, World Food Summit,1, Sec.1.4

[31] Frimpong, S., \& Asuming-Brempong, S. (2013). Comparative Study of Determinants of Food Security in Rural and Urban Households of Ashanti Region, Ghana. International Journal of Economics and Management Sciences, 2(10): 29-42.

[32] Hakim, E. (2020). Preventing the spread of COVID-19 in South Sudan. Medical Journal, 13(2): 40-43.

[33] Global Hunger Index (2011) Forced Migration and Hunger. Available at http://www.globalhungerindex.org/

[34] Global Hunger Index (2012) Forced Migration and Hunger. Available at http://www.globalhungerindex.org

[35] Global Hunger Index (2013) Forced Migration and Hunger. Available at http://www.globalhungerindex.org/nigeria.html

[36] Global Hunger Index (2014) Forced Migration and Hunger. Retrieved from http://www.globalhungerindex.org/nigeria.html 
[37] Gurkan, A.A. (1995). The Mathematics of Hunger. Ceres. The FAO Review 27(2): 31-33

[38] Hamilton, W.L., Cook, J., m Thompson, W.W., Buron, L.P., Frongillo, E.A., Olison, C.M. and Welder, C.A. (1997). Household Food Security in United States in 1995. Summary Report of Food Security Measurement Project. Washington DC, US Department of Agriculture.

[39] Helleiner, G.K. (1996). Present Agricultural and Economic Growth in Nigeria, Homewood Publisher, United Kingdom.

[40] Henri-Ukoha A, Ibekwe U.C., Chidiebere-Mark N.M., Ejike R. and Oparadim (2013). Determinants of food security in female-headed households involved in individual tenure system in Abia State, Southeast Nigeria. Global Journal of Agricultural Research 1(2): 48-57.

[41] Hoddinott, J. and Yohannes, Y. (2002). Dietary diversity as a food security indicator. FANTA, Washington DC. available at http://www.aed.org/Health/upload/dietarydiversity.pdf

[42] Ibrahim H., N.R. Uba-Eze, S.O. Oyewole and E.G. Onuk (2009). Food security among urban households: A case study of Gwagwalada area council of the federal capital territory Abuja, Nigeria. Pakistan Journal of Nutrition $8(6): 810-813$

[43] Ibok, O. W., Bassey, N. E., Atairet, E. A., \& Obot, O. J. (2014). Food Security Determinants among Urban Food Crop Farming Households in Cross River State, Nigeria. Asian Journal of Agricultural Extension, Economics \& Sociology 3(1), 76-90.

[44] Ibok, O. W., Idiong, I. C., Bassey, N. E., \& Udoh, E. S. (2014). Food Security and Productivity of Urban Food Crop Farming Households in Southern Nigeria. Agricultural Science 2(3), 1-12. DOI: https://doi.org/10.12735/as.v2i3p01

[45] Idachaba, F.S. (2004). Food Security in Nigeria: Challenges under Democratic Dispensation. 9th ARMTI Annual Lecture, Ilorin, 24/3/2004.

[46] Irohibe, I. J., \& Agwu, A. (2014). Assessment of Food Security Situation among Farming Households in Rural Areas of Kano State, Nigeria. Journal of Central European Agriculture, 15(1): 94-107. DOI: https://doi.org/10.5513/JCEA01/15.1.1418

[47] Kennedy, G., Pedro, M.R., Seghieri, C., Nantel, G. and Brouwer, I. (2007). Dietary diversity score is a useful indicator of micronutrient intake in non-breast-feeding Filipino children. Journal of Nutrition 137: 1-6.

[48] Kruger, R., Schonfeldt, H.C. and Owen, J.H. (2008). Food-Coping Strategy Index Applied to a Community of Farm-Worker Households in South Africa. Food Nutrition Bullettin 29(1):13-14 DOI: https://doi.org/10.177/156482650802900101

[49] Matemilola, S. and Elegbede, I. (2017). The challenges of food security in Nigeria. Open Access Library Journal, 4: 1-22. DOI: https://doi.org/10.4236/oalib.1104185

[50] Maxwell, D.C., Ahiadeke, M., Armer-Klemesu, S., Zakariah, A. and ～Lamptey, G.M. (1999). Alternative Food Security Indicators: Revisiting the Frequency and Severity of Coping Strategies. Food Policy, 24(4): 411-430.

[51] Maxwell, S. (1996). 'Food Security: A Post-Modern Perspective.' Food Policy.21(2): 155-170.

[52] Maxwell, S. and Smith, M. (1992). Household Food Security; A Concept Review', In: Maxwell, S. and T.R. Frankenberger. (Eds.) Household Food Security: Concepts, Indicators, Measurements: A Technical Review. New York and Rome: UNICEF and IFAD.

[53] Maxwell. D., Watkins, B., Wheeler, R. and Collins, G. (2003). The Coping Strategies Index. Field Methods Manual. Nairobi, Kenya: CARE and World Food Programme.

[54] Muche, M., \& Tadele, E. (2015). Analysis of Household Level Determinants of Food Security in Jimma Zone, Ethiopia. Journal of Economics and Sustainable Development, 6(9): 230-241.

[55] National Bureau of Statistics (NBS) (2012). Consumption Pattern in Nigeria 2009/10 Preliminary Report March 2012.

[56] National Bureau of Statistics (NBS) (2012). Federal Ministry of Agriculture and Rural Development Collaborative Survey on National Agriculture Sample Survey (NASS), 2010/2011Draft Report, May 2012.

[57] Nigeria Millennium Development Goals (MDGs) End-point report, (2015). UNDP in Nigeria. available at https://www.ng.undp.org/content/nigeria/en/home/library/mdg/nigeria-mdgs-end-point-report2015.html

[58] Obasan, T. A., Okojie, L. O., \& Okuneye, P. A. (2017). Determinants of Rural Households' Food Security in Ogun St Ate, Nigeria. Conference Proceedings of the 18th Annual National Conference of The Nigerian 1ssociation of Agrirnltural Economists Held Federal University of Agriculture, Abeokuta, Nigeria 16 - 19th October 2017. 
Assessment of Rural Households Food Insecurity During Covid-19 Pandemic in South-East Nigeria

[59] Olagunju, F. I., Oke, J. T. O. Babatunde, R.0 and Ajiboye, A. (2012). Determinants of food insecurity in Ogbomoso metropolis of Oyo State, Nigeria: PAT. 8 (1): $111-124$

[60] Omotesho, O.A., Adewumi, M.O. and Fadimula, K.S., (2007). Food security and poverty of the rural households In Kwara state, Nigeria. AAAE Conference Proceedings. pp. 571-575.

[61] Omotesho, O. A., Adewumi, M. O., \& Ayinde, O. E. (2006). Determinants of Food Security Among the Rural Farming Households in Kwara State, Nigeria. African Journal of General Agriculture, 2(1): 7-15.

[62] Onunka, C., Ihemezie, E. J., \& Olumba, C. C. (2018). Household Level Analysis of Food Insecurity and Coping Strategies: Evidence from Enugu State, Nigeria. Advances in Social Sciences Research Journal, 5(6): 330-340. DOI: https://doi.org/10.14738/assrj.56.4764

[63] Otu W. I., Nsikan E. B., Elizabeth A. A. and Oto-obong J. O. (2014). Food Security determinants among urban food crop farming households in Cross River State, Nigeria. Asian Journal of Agricultural Extension, Economics \& Sociology, 3(1): 76-90

[64] Oyebanjo, O., Ambali, O. I., \& Akerele, E. O. (2013). Determinants Of Food Security Status And Incidence Of Food Insecurity Among Rural Farming Households In Ijebu Division Of Ogun State Nigeria. Journal of Agricultural Science and Environment, 13: 92-103.

[65] Oyeleye O.A. and Adebisi O.A. (2014) Assessment of Farm Household Food Security and Consumption Indices in Nigeria. Asian Journal of Agriculture and Rural Development, 4(9): 458-464.

[66] Quisumbing, A. (2007). Poverty transitions, shocks, and consumption in rural Bangladesh: Preliminary results from a longitudinal household survey. CPRC Working Paper-105.

[67] Ruel, M., Graham, J., Murphy, S. and Allen, L. (2004). Validating simple indicators of dietary diversity and animal source food intake that accurately reflect nutrient adequacy in developing countries. Report submitted to GL-CRSP.

[68] Savy, M., Martin-Prevel, Y., Traissac, P., Emyard-Duvernay, S. and Delpeuch, F. (2006). Dietary diversity scores and nutritional status of women change during the seasonal food shortage in rural Burkina Faso. Journal of Nutrition 136: 2625-2632.

[69] Savy, M., Martin-Prevel, Y., Sawadogo, P., Kameli, Y. and Delpeuch, F. (2005). Use of variety/ diversity scores for diet quality measurement: relation with nutritional status of women in a rural area in Burkina Faso. European Journal of Clinical Nutrition 59: 703-716.

[70] Snel, E. and Staring, R. (2001). Poverty, Migration, and Coping Strategies: An Introduction. European Journal of Anthropology, 38: 7-22.

[71] Soma, G. J. (2020). Communicating to children about the COVID-19 pandemic. Medical Journal, 13(2): 60-63.

[72] Steyn, N.P., Nel, J.H., Nantel, G., Kennedy, G. \& Labadarios, D. (2006). Food variety and dietary diversity scores in children: are they good indicators of dietary adequacy? Public Health Nutrition 9(5): 644-650.

[73] Vos, R., Martin, W., \& Laborde, D. (2020, March 10). As COVID-19 spreads, no major concern for global food security yet. Washington, DC: International Food Policy Research Institute [Blog post]. Retrieved from https://www.ifpri.org/blog/covid-19-spreads-no-major-concern-global-food-security-yet

[74] Wiehl DG (1942): Diets of a group of aircraft workers in Southern California. Milbank Mem. Fund Q. 20: 329 366.

[75] World Bank, (1986). Poverty and hunger: Issues and options for food security in developing countries. A World Bank policy study. Washington D.C: World Bank.

[76] Zurayk, R. (2020). Pandemic and Food Security: A View from the Global South. Journal of Agriculture, Food Systems, and Community Development. DOI: https://doi.org/10.5304/jafscd.2020.093.014. 